\title{
Co je rozmanité a co je společné v inkluzivní škole z hlediska Ukazatele inkluze
}

\author{
Josef Slowík \\ Západočeská univerzita v Plzni, Fakulta pedagogická, Katedra pedagogiky \\ Redakci zasláno 14. 2. 2018 / upravená verze obdržena 18. 7. 2018 / \\ k uveřejnění přijato 18. 7. 2018
}

\begin{abstract}
Abstrakt: Studie analyzuje na základě parametrů tzv. Ukazatele inkluze (Booth \& Ainscow, 2007) základní charakteristiky inkluzivního vzdělávání související s přístupem k odlišnosti (resp. rozmanitosti). V první části je představeno paradigma inkluzivní edukace a to, jak se inkluze vztahuje k tématu „společného“ a „rozdílného“. Typická proinkluzivní otevřenost ke vstřícnému akceptování různosti a jinakosti je postavena do souvislostí se spojujícími a stmelujícími prvky, které symbolizují společné hodnoty, z nichž edukační proces v inkluzivní škole vychází. Další část je pak věnována tematické analýze Ukazatele inkluze (ve verzi jeho českého překladu; viz Booth \& Ainscow, 2007) jako základního materiálu, který nejčastěji slouží pro vymezování norem školní inkluzivní edukace a jejich evaluaci. Na základě analýzy parametrů všech inkluzivních oblastí a jejich evaluačních měřítek byla identifikována čtyři zásadní témata odrážející přístup inkluzivní školy k odlišnostem: akceptace (ve smyslu vzájemného přijetí, tolerance apod.), dostupnost (jako bezbariérovost prostor, ale také psychosociální bezbariérovost $\mathrm{v}$ rámci školy i vzhledem k okolí komunitě nebo dostupnost zdrojů), podpora (v samotném edukačním procesu, ale třeba i v adaptaci žáků) a antidiskriminace (nejenom formální, ale jako široce pojatá důsledná rovnocennost).
\end{abstract}

Klíčová slova: inkluze, inkluzivní vzdělávání, Ukazatel inkluze (Booth \& Ainscow, 2007), rozmanitost

Inkluze ve vzdělávání se stala tématem nejenom diskutovaným pedagogickými odborníky, učiteli, psychology, sociology, ale i tématem silně politizovaným a následně veřejně a hlasitě medializovaným. Je přitom zřejmé, že $\mathrm{v}$ porozumění podstatě a koncepci inkluze, stejně jako v terminologickém a definičním vymezení inkluzivního vzdělávání, zdaleka nepanuje jednota (srov. Farrell \& Ainscow, 2002), a to ani mezi erudovanými profesionály, akademickými osobnostmi a autory souvisejících zásadních tematických publikací (kterých se u nás objevilo doposud jen málo). To, v čem se všechna pojetí a prŕístupy shodují, je reflektování pozitivního vztahu inkluzivních struktur 
(školy, komunity, společnosti) k rozmanitosti, různosti, resp. odlišnosti svých členů - jak stávajících, tak i těch potenciálních. V této studii se zaměřujeme na otázku vymezování odlišnosti (rozdílnosti, jinakosti) v inkluzivním vzdělávání a identifikování „nástrojü“, pomocí kterých může inkluzivní škola reagovat na rozmanitost tak, aby dosahovala jednoho z důležitých deklarovaných cílů inkluze, totiž vytváření funkčního a koherentního společenství (Ainscow, Booth, \& Dyson, 2006).

\section{Inkluzivní vzdělávání a charakteristiky inkluzivní školy}

Inkluzivní přístup ve vzdělávání bývá obvykle představován z více hledisek - např́klad lidskoprávního, sociálního, etického, psychologického, didaktického (metodologického), ale i politického (srov. např. Ainscow et al., 2006). Lechta (2016) však upozorňuje také na význam filozofických východisek, když vytýká současným pokusům o vymezení podstaty inkluzivního vzdělávání nedostatečné axiologické a kulturní zakotvení, které by odpovídalo aktuálnímu společenskému paradigmatu. Inkluzivní pedagogika by se podle tohoto autora dala představit $\mathrm{v}$ globálních souvislostech dokonce jako humanistický edukační přístup pomáhající řešit deficit lidství v současném světě. Navzdory mezinárodnímu a stále důraznějšímu prosazování inkluze v oblasti vzdělávání ale zůstává téma sociální inkluze (tedy inkluze v širším společenském prostoru) i nadále spíše kontroverzním tématem žhavých diskuzí (Farrell \& Ainscow, 2002).

\subsection{Co je a co není inkluze}

$\mathrm{Na}$ nejednotnost definice inkluze a inkluzivního vzdělávání upozorňuje většina autorů (srov. např. Farrell \& Ainscow, 2002). Důvodem je mimo jiné to, že inkluze znamená pro různé lidi rủzné věci (Armstrong, Armstrong, \& Spandagou, 2010; srov. Imray \& Colley, 2017). Nacházíme proto definice odrážející užší nebo naopak širší vymezení inkluzivní edukace (tedy zaměřené na konkrétní znevýhodněné a exkluzí ohrožené skupiny, anebo naopak s důrazem na přizpůsobení běžné školy pro všechny žáky bez výjimky srov. např. Westwood, 2013). Ainscow a kol. (2006) rozlišují škálu různých definic inkluze a inkluzivního vzdělávání na deskriptivní (reflektující různé způsoby implementace inkluze ve vzdělávací praxi) a preskriptivní (představující jakousi nabídku „ideálního“ porozumění konceptu inkluze). Inkluzi nelze zjednodušeně chápat jen jako pouhý opak (nebo negaci) exkluze (ta se 
soustředí jen na určité jedince nebo skupiny odlišné od majoritní populace, zatímco inkluze je záležitostí celé společnosti, která musí být ochotna začleňovat a respektovat i podstatné odlišnosti u různých jedinců a skupin). Jako vhodné se jeví pozitivní definování inkluze na základě typických charakteristik; typické znaky inkluze přitom spočívají především v implementaci inkluzivních hodnot, jakými jsou spravedlivý přístup, participace všech, budování společenství - nebo právě respekt k odlišnostem (srov. Armstrong et al., 2010; Ekins, 2017).

Přestože optimální definici inkluze teprve hledáme, samotný koncept inkluzivní edukace není ve skutečnosti až tak nový, jak by se mohlo zdát (např. z mimořádně intenzivní diskuze tohoto tématu v posledních několika letech). Lechta (2016) jasně zachycuje ve svém popisu historické geneze inkluzivní edukace typické prvky tohoto pojetí u některých reformních pedagogických směrů už na počátku 20. stol. (např. Montessori nebo waldorfských škol) a další aktivity, spíše jednotlivé a izolované, pak v průběhu celého minulého století. Jen tak bylo nakonec možné dospět až ke známému prohlášení konference UNESCO ve španělské Salamance v roce 1994, které je obvykle citováno jako iniciační dokument pro současnou vlnu inkluzivních trendů ve vzdělávání v mezinárodním měřítku (srov. např. Farrell \& Ainscow, 2002; Lechta, 2016). ${ }^{1}$ Jakkoliv je dnes pojem inkluze skloňován nejčastěji právě v souvislosti se školním vzděláváním, ve skutečnosti se inkluze - stejně jako samotné vzdělávání - netýká nikdy pouze školy, ale zasahuje vždy také širší sociální prostředí (Armstrong et al., 2010).

V souvislosti s obtížným vymezením podstaty inkluze také stále narážíme na diskuzi nad ne zcela vyjasněnými pojmy integrace a inkluze, a to i v související odborné literatuře; $v$ jedné $\mathrm{z}$ nejnovějších zásadních publikací s mezinárodním zázemím autorského týmu v tom přiznává jisté tápání rovněž již citovaný Lechta (2016). Problematické je také obvyklé spojování termínu inkluzivní vzdělávání především nebo výhradně se žáky se speciálními vzdělávacími potřebami (resp. se zdravotním postižením), přestože mnozí poukazují na to, že inkluze se týká všech žáků (a nejenom žáků) školy (srov. např. Brown, 2016; Farrell \& Ainscow, 2002). Brown (2016) přímo varuje před nahlížením na inkluzi jako na pouhé zařazování žáků se speciálními vzdělávacími potřebami do běžných škol a tříd (což podle jeho zkušenosti bývá časté zejména u vedení škol a učitelů), kdy téměř uniká

1 Dostupné např. na http://osf.cz/publikace/prohlaseni-ze-salamanky/ 
požadavek přizpůsobení školy směrem $\mathrm{k}$ její celkové otevřenosti a přístupnosti pro všechny - samozřejmě včetně žáků se speciálními vzdělávacími potřebami (srov. také Ainscow et al., 2006). Stejný autor pak rozlišuje celkem tři úrovně inkluze: povrchovou (nebo také „povrchní"), která je pouze zohledněním nevyhnutelného politického trendu tzv. „společného vzdělávání“, dále střední, při které už dochází k výrazným a podstatným změnám ve školní praxi, teprve třetí úroveň je ale označena jako hluboká a jejím typickým znakem je zvnitřňování inkluzivních hodnot. ${ }^{2}$

Jako „přístup rozvíjející kulturu školy směrem k sociální koherenci a respektující právo na adekvátní vzdělávání pro všechny" charakterizují inkluzivní vzdělávání Hájková a Strnadová (2010). ${ }^{3}$ Upozorňují přitom, že současný „jednosměrný tlak na inkluzivní uspořádání škol má někdy za následek pouhou ,fyzickou inkluzi', kdy je prosazena účast nejrůznějších minorit ve ,většinové škole, ale přítomní žáci z těchto minorit nejsou dostatečně přijímáni ani svými spolužáky, ani svými pedagogy; k inkluzi v rovině emocionální a sociální tedy ve skutečnosti nedochází." (s. 91). Podobně se vyjadřují i Dinh Thi a Le Thu (2010) - ti tvrdí, že i když bude inkluze ve vzdělávání vymáhána zákonem, nebude smysluplná, pokud se nesetká s pozitivním postojem a vnitřním nadšením těch, kdo ji budou realizovat. Forlin (2010) dokonce označuje pozitivní postoj a nadšení pro inkluzi jako zásadní stimul podporující kreativitu učitelů, která v případě opačného (odmítavého) postoje naopak spíše upadá.

Jestliže chceme nahlédnout na inkluzivní školní praxi, tu charakterizuje Brown (2016) zejména rovnoprávností a férovostí (žáci školy pocházejí z různého sociálního prostředí např́ćc celou komunitou, mají různou úroveň potřeb a schopností a všichni dostávají příležitost), participací všech (všichni mohou vyjadřovat své názory, klást otázky, sdělovat myšlenky), bezpečím (ve škole není přípustná žádná psychická ani fyzická šikana, žádná izolace nebo osamocení některých jedinců nebo skupin) a také adekvátní podporou (učitelé i další zaměstnanci pomáhají žákům a současně je stimulují, aby se

Zde můžeme jasně zahlédnout riziko současného nahrazování termínu inkluzivní vzdělávání spojením společné vzdělávání. Zjevně však nejde o synonyma - zatímco společné vzdělávání je vždy nezbytnou součástí inkluze, naopak to neplatí a žáky lze vzdělávat sice společně, ale přitom neinkluzivně!

3 Právě lidskoprávní důraz (tedy důraz na rovnoprávnost ve vzdělávání) zařazuje Lechta (2016) mezi tzv. „etické komponenty inkluzivní pedagogiky“, která je podle něj spojena vždy s nezbytným požadavkem úcty a bezvýhradného přijetí jedince nebo skupiny, a to navzdory jejich odlišnostem. 
učili nové věci a byli připraveni i na nezdar). Ekinsová (2017) označuje jako zásadní prvek inkluzivní školy zejména poskytování srovnatelné vzdělávací zkušenosti pro všechny.

Podle Hornbyho (2014) jsou inkluzivní školy charakteristické zejména:

- filozofií přijetí a začleňování do komunity;

- filozofií vzájemné spolupráce žáků, rodičů, učitelů a širší komunity;

- oceňováním odlišnosti (jedinečnosti) a hodnoty každého žáka;

- hodnotou vysoké kvality vzdělávání žáků;

- hodnotou vzdělávání všech žáků společně s vrstevníky;

- hodnotou vzdělávání všech žáků v běžných školách;

- hodnotou vzdělávání všech žáků v prostředí jejich místní komunity.

Zachytil tak v podstatě souhrn toho esenciálně „společného“, co je od inkluzivních škol vždy očekáváno. $V$ úvahu je ovšem třeba také brát, že konkrétní praktická implementace dosud pevně nezakotveného a celkově velmi komplexního konceptu inkluze je výrazně ovlivňována rovněž politickými vlivy a kulturní interpretací v jednotlivých geografických lokalitách (Ekins, 2017).

Pojetím toho „rozmanitého" v inkluzivní edukaci a tím, jak si inkluzivní škola dokáže (nebo by si měla dokázat) poradit i se značnými rozdílnostmi a odlišnostmi (nejenom) mezi žáky, se budeme zabývat dále.

\subsection{Paradigma společného a odlišného v inkluzivním edukaci}

Principem inkluzivního přístupu je podle většiny autorů především respekt k odlišnosti a k právu každého jedince na rovnocenné členství v komunitě a společnosti (srov. např. Ainscow et al., 2006; Lombardi, 1999). Inkluze předpokládá heterogenitu žáků, která je základní charakteristikou a jednou z nezměnitelných podmínek skutečně inkluzivní školy (Hájková \& Strnadová, 2010; srov. Bartoňová et al., 2016); žáci mohou být rozdílní co se týče pohlaví, temperamentu, mateřského jazyka, náboženství, národnosti, výkonu, věku i řady dalších faktorů, které jsou různě významné vzhledem k výchově a vzdělávání (Westwood, 2013). Rozdílnost žáků může být vnímána jako přirozená samozřejmost a přínos, může se $\mathrm{z}$ ní stát ale i problém, jestliže $\mathrm{s}$ ní škola neumí správně zacházet. Inkluzivní vstřícnost vůči rozdílnostem má řadu dobrých důvodů - především jsou to důvody (Bartoňová et al., 2016): 
- humánní (úcta k druhým lidem a jejich životu);

- právní (respektování rovnoprávného přístupu ke všem); také

- pragmatické (profit z kontaktu s odlišnými lidmi, obohacení o nové úhly pohledu, nové informace, nové zkušenosti...).

Ani rozdílné schopnosti žáků nejsou v inkluzivním vzdělávání považovány za rušivé faktory, měřítkem pro evaluaci je zde totiž individuální potenciál a optimum každého jednotlivého žáka. Jakákoliv odlišnost je sama o sobě v podstatě spíše kulturním determinantem a může být vnímána negativně jako cizost, nebo (v interkulturním rámci) pozitivně jako zcela přirozená forma diverzity (srov. Brown, 2016; Farrell \& Ainscow, 2002 a další). Bartoňová a kol. (2016) dokonce vidí inkluzivní školu jako spojení interkulturní a integrativní pedagogiky. Za zmínku stojí zjištění Ekinsové (2017), že rozdílnosti jsou nejenom předpokladem, ale pravděpodobně i katalyzátorem dobré inkluzivní praxe. Její výzkumné studie totiž prokázaly, že školy, které si musí poradit s větši škálou rozdílností svých žáků, vykazují větší tendenci implementovat inkluzivní hodnoty a naplňovat kritéria inkluzivní edukace.

Zajímavé je, že diferenciace ve vzdělávání, kdy dochází k rozlišování různých jedinců a skupin, je v některých případech zcela běžně akceptovaná jako správná a přirozená, resp. neutrální (např. diferenciace podle věku nebo stupňů vzdělávání v malotřídní škole; tomu se pak přirozeně přizpůsobuje všechno - vybavení třídy, metody a formy vyučování, časové rozvržení, př́stup, a dokonce i kvalifikace učitele); jestliže ale to samé v běžné škole provedeme třeba u žáků s tělesným nebo zrakovým postižením (tedy přizpůsobíme pro ně adekvátně prostředí a přístup ke zdrojům ve smyslu zajištění bezbariérovosti, speciálních pomůcek, upravených materiálů atd.), je to už chápáno jako „specifická inkluzivní podpora“ (Armstrong et al., 2010). Důrazem na respektování a zohledňování odlišností ovšem na tyto odlišnosti zároveň upozorňujeme a narážíme tak na tzv. dilema inkluze (Brown, 2016). Identifikací speciálních vzdělávacích potřeb a nároků na nezbytnou podporu dochází totiž v běžných školách často k efektu označování konkrétních žáků ve smyslu labelingu (tedy „nálepkování“), který skrývá značná rizika (Artiles, Kozleski, \& Waitoller, 2011).

Myšlenky inkluze obecně vycházejí z požadavků rovnoprávnosti a sociální spravedlnosti (Brown, 2016). Inkluzivní rovnost v přístupu ke všem žákům ale neznamená očekávání stejných výkonů nebo uplatňování stejných 
postupů (např. vzdělávacích metod) v jejich edukačním procesu. Právě to však bývá stále požadavkem současné školy i společnosti: pokud chce být žák plně začleněn, musí se přizpůsobit se vším všudy (tedy obstát i v soutěži, účastnit se všeho jako ostatní - zkrátka být srovnatelný), což představuje silný asimilační tlak. Ekinsová (2017) varuje před nesprávným chápáním inkluze ve smyslu jakési uniformity. Inkluze naopak přirozeně očekává různost ve všem - i ve výkonu: každý se učí jinak, a každý proto dosáhne jinou úroveň výsledků. Heterogenita v inkluzivní edukaci tedy předpokládá spravedlivý přístup k odlišným jedincům (Artiles et al., 2011). Aby však byl takový edukační přístup efektivní a smysluplný, musí v co největší míře korespondovat $\mathrm{s}$ obdobným př́ístupem $\mathrm{k}$ odlišnosti (rozmanitosti) v okolní komunitě a nejlépe i v celé většinové společnosti (Brown, 2016). Ainscow (2015) označuje inkluzivně orientované běžné školy přímo jako ten „nejefektivnější nástroj k potírání diskriminace, budování inkluzivní společnosti a zpř́ístupňování kvalitního vzdělávání pro všechny." Inkluzivní školy by proto měly být nahlíženy spíše jako zdroje podpory vzdělávání a kvalitního soužití pro celou místní komunitu, než pouze jako poskytovatelé nezbytných vzdělávacích příležitostí (resp. služeb) pro své žáky (Ainscow et al., 2006).

\section{Tematická analýza Ukazatele inkluze}

Je zřejmé, že koncept inkluzivního vzdělávání není doposud vymezen a ukotven tak pevně, aby nebylo možné jím prakticky „viklat“ do všech stran. Přesto existují některé záchytné body a dokumenty, které paradigma inkluzivního vzdělávání jistým způsobem ohraničují a jsou akceptovány víceméně jako normativní (přestože si samy tento nárok nekladou). Základním materiálem, který plní roli inspirativní směrovky či mapy ukazující směr k ideálu inkluzivního vzdělávání, a současně také evaluačním nástrojem umožňujícím posuzovat okamžitou míru inkluzivity konkrétní školy je v našich podmínkách (a patrně v evropském nebo mezinárodním kontextu) tzv. Ukazatel inkluze (Index for Inclusion), jehož autory jsou Tony Booth a Mel Ainscow (2007). Jak sami upozorňují, výsledek jejich tříletého ověřování tohoto nástroje představuje velmi volný materiál, nikoliv návod typu „postupujte přesně podle instrukcí", ačkoliv by o to mnozí uživatelé stáli (Booth \& Ainscow, 2002). Cílem Ukazatele je především podpora inkluzivních škol. Nepředstavuje žádnou novou iniciativu ani alternativní cestu k lepším výsledkům školy, pouze ukazuje jeden z možných způsobů, jak zlepšit působení škol v souladu s inkluzivními hodnotami. Podle Ainscowa (2015, s. 111) jsou 
inkluzivní školy především „školami v neustálém pohybu, nikoliv školami, které dosáhly určitého dokonalého stavu“.

Autoři nepředkládají dokonce ani žádnou stručnou či souhrnnou definici inkluze - naopak inkluzi chápou jako neustálý proces zkvalitňování společného vzdělávání pro všechny žáky (nikoliv pouze pro žáky se speciálními vzdělávacími potřebami) a pojetí i definování tohoto procesu považují za neustálené a neustále pohyblivé. Výčet charakteristik inkluzivní školy (který se stal už jakýmsi etalonem inkluzivní edukace) je podle Ukazatele inkluze následující (Booth \& Ainscow, 2002):

- Všichni studenti a pracovníci školy jsou stejně důležití.

- Zvyšuje se míra zapojení studentů (snižování míry vyčlenění) do školní kultury, vzdělávacího procesu a komunity.

- Školní kultura, politika a praxe se mění tak, aby byla zohledněna různorodost studentů.

- Odstraňují se překážky v učení a zapojení všech studentů, tedy nejen těch, kteří mají určité postižení či jsou označeni jako „studenti se speciálními vzdělávacími potřebami“.

- Využívají se zkušenosti z konkrétních př́ípadů překonávání překážek v přístupu a zapojení tak, aby ze změn mohli čerpat i ostatní studenti.

- Rozdíly mezi studenty jsou vnímány jako inspirace pro podporu učení, nikoliv jako problém, který je třeba řešit.

- Je respektováno právo studentů na vzdělávání v místě, kde žijí.

- Škola je zkvalitňována pro potřeby studentů i učitelů.

- Je zdůrazňována úloha školy při budování společenství a rozvoji hodnot, ne jen při zvyšování výkonů studentů.

- Jsou podporovány vzájemně prospěšné vztahy mezi školou a okolní komunitou.

- Zohledňuje se myšlenka, že inkluze ve vzdělávání je jedním z aspektů inkluze ve společnosti.

Autoři záměrně preferují termín „překážky v učení a zapojení žáků“ před termínem „speciální vzdělávací potřeby“. Vycházejí přitom ze sociálního modelu 
problémů ve vzdělávání, podle kterého mohou překážky v učení a účasti existovat $\mathrm{v}$ samotné podstatě vzdělávacího prostředí nebo vznikat $\mathrm{v}$ interakci mezi žáky a jejich okolím (nejsou tedy nezbytně např. důsledkem postižení žáka). Opět se tedy máme vyhýbat zúžení inkluze na skupinu žákủ se zdravotním postižením nebo jiným parciálním znakem. Paradoxně však Ukazatel $\mathrm{v}$ popisu jednotlivých evaluačních charakteristik upozorňuje konkrétně např́klad na určité specifické etnické a kulturní odlišnosti některých žáků, nepodařilo se zde tedy zcela vyhnout riziku zúžení (dokonce z dnešního pohledu autoři balancují místy až na hraně labelingu - byt' v dobrém úmyslu).

Základním požadavkem Ukazatele inkluze je připustit diverzitu mezi žáky a respektovat ji při prŕípravě a aplikaci inkluzivních přístupů $\mathrm{k}$ vyučování a učení. To může znamenat rozsáhlé změny ve třídách i ve sborovnách, na školních hřištích nebo ve vztazích pedagogů s rodiči. Žák musí být pro školu zajímavý z pohledu celé jeho osobnosti. Samozřejmě, že se škola nedokáže vypořádat například se samotným zdravotním postižením žáka, může ale do značné míry zredukovat omezení, která vznikají z diskriminačních postojů a př́stupů nebo $\mathrm{z}$ institucionálních bariér. Exkluze totiž podle autorů Ukazatele nemá vždy pouze formu skutečného fyzického vyloučení žáka (např. do prostředí segregované speciální školy), ale jsou to všechny překážky, které brání jeho plné akceptaci a participaci v prostředí běžné školy (např. neúspěšnost ve zvládání učiva, negativní hodnocení, neporozumění sociokulturnímu zázemí žáka apod.). Naopak individuální podpora nezbytná pro některé žáky může pomoci nejenom větší míře aktivity a samostatnosti těchto žáků, ale současně i zkvalitnit výuku v celé skupině (Booth \& Ainscow, 2002). Autoři Ukazatele nabízejí a odůvodňují řadu př́mých a konkrétních změn ve školství (včetně např. změny označení tenkrát již v britském školství etablované pozice „koordinátorů speciálních vzdělávacích potřeb“, která se $\mathrm{v}$ současnosti pilotně ověřuje $\mathrm{v}$ rámci některých projektů i $\mathrm{v}$ českých školách pod novým názvem „koordinátor inkluze“). Nepovažují přitom takovéto zdánlivě nadbytečné změny pojmů jako vytváření zmatků, ale jako pochopení neustálého vývoje situace a zpřesňování jazykové kodifikace důležitých prvků v inkluzivní edukaci - mimo jiné i v souvislosti s vývojem společenského paradigmatu. Opravdu tedy nemáme co do činění pouze s technologickým návodem k praktickému provedení inkluze; Armstrong a kol. (2010) považují Ukazatel inkluze přímo za globalizovaný nástroj, který je sice kulturně podmíněný, ale současně operuje (jako i celý koncept inkluze) s hodnotami, které jsou nadkulturní a nadnárodní (lidská práva, sociální spravedlnost apod.). 
Struktura Ukazatele inkluze spočívá ve třech oblastech důležitých pro rozvíjení a hodnocení inkluzivního vzdělávání. Každá z nich zahrnuje dva okruhy, takže základní rámec vypadá následovně:

Oblast A - Inkluzivní kultura

- Okruh A.1 Budování komunity

- Okruh A.2 Stanovení inkluzivních hodnot

Oblast B - Inkluzivní politika

- Okruh B.1 Vytváření školy pro všechny

- Okruh B.2 Podpora různorodosti

Oblast C - Inkluzivní praxe

- Okruh C.1 Organizace učení

- Okruh C.2 Mobilizace zdrojů

V každém okruhu je definováno několik parametrů (5-11), které slouží jako konkrétní dosažitelné cíle a současně (sebe)hodnoticí kritéria během celého procesu vytváření inkluzivní školy. Autoři zde zároveň explicitně ponechávají značnou volnost - ne všemi měřítky se každá škola (a ve všech fázích) musí zabývat a očekává se naopak doplnění nebo jiná adaptace materiálu podle potřeb a situace konkrétní školy (je nereálné vytvořit zcela univerzální kvalitní nástroj použitelný beze změny pro všechny školy bez ohledu na jejich velikost, podmínky, složení žákủ atd.). ${ }^{4}$ Obecný a společný rámec pro inkluzivní nasměrování by přitom měla vždy určovat aktuální legislativa.

Ukazatel inkluze nabízí škole pomoc ve snaze „převzít určitou míru kontroly nad vlastním inkluzivním rozvojem, analyzovat stávající praxi, stanovit

4 V českém prostředí existuje několik materiálů vycházejících z původního Ukazatele inkluze všechny jsou jeho odvozenou a adaptovanou alternativou. Patrně nejznámější je nástroj vytvořený Tannenbergerovou (2016), který využívá i projekt Ligy lidských práv Férová škola (http://www.ferovaskola.cz/standardy-ferove-skoly) a následně jej převzalo např́klad i MŠMT ČR při zpracování metodického materiálu pro hodnocení školy v oblasti inkluze u škol zapojených do projektů v rámci OP VVV v prioritní ose 3 - Inkluzivní vzdělávání (viz http:// www.msmt.cz/strukturalni-fondy-1/hodnotici-formular-na-prokazani-indikatoru-5-10-15vyzvy-po3). Oproti původní verzi Ukazatele vymezuje čtyři tematické oblasti namísto tří, a to kulturu (kultura, politika, postoje), podmínky (materiální, organizační, personální), praxi (didaktika, individualizace, hodnocení) a relace (vztahy, komunikace, spolupráce); jejich struktura i terminologie celkově více odpovídají současným českým reáliím než originální verze Ukazatele inkluze. 
si priority a uvést je do života" (Booth \& Ainscow, 2002). Druhá (centrální) část materiálu je proto věnována jakémusi ukázkovému (modelovému) detailnímu průvodci komplexním a efektivním použitím tohoto nástroje v praxi běžné školy. Celý proces má vést k vytvoření plánu inkluzivního rozvoje školy a jeho následné realizaci jako jedné z hlavních priorit školy. Tento rozvoj musí být ale udržitelný (a cíleně udržovaný), hodnotitelný (a pravidelně evaluovaný) - a v neposlední řadě také korigovatelný (má jít skutečně o proces neustále otevřený, nikdy nekončící, a tedy stále živý).

Tematické analýze jsme podrobili třetí (nejrozsáhlejší a nejdůležitější) část Ukazatele inkluze, která obsahuje měřítka a kritéria vymezující a posuzující úroveň „inkluzivity“ školy ve všech třech sledovaných oblastech - tedy v oblasti její inkluzivní kultury, inkluzivní politiky i inkluzivní praxe.

\subsection{Metodologie a realizace analýzy}

Pro zachycení pojetí rozmanitosti v inkluzivní škole a př́stupu k ní se jeví právě tematická analýza Ukazatele inkluze (resp. jeho 3. části Měř́tka a otázky) jako vhodná metoda kvalitativního zkoumání, která hledá významy skryté pod povrchem (Jandourek, 2008). Její výhodou je, že činí skryté zjevnějším, přestože interpretace významu je přitom velmi subjektivní. Boyatzis (1998) dokonce přirovnává tematickou analýzu $\mathrm{k}$ učení se novému jazyku a označuje ji za specifický způsob vidění (nahlížení), při kterém je přirozené, že to, co vidí jeden určitým způsobem, mohou ostatní vidět jinak. Rovněž Miovský (2006) považuje obsahovou analýzu za velmi volnou; pokud však výzkumník explicitně seznámí čtenáře s perspektivou nahlížení na předmět svého zájmu, vymezuje tím přece jenom zřetelněji hranice svého počínání, jakkoliv zůstává tato metoda stále velmi závislá na subjektivním přínosu výzkumníka.

Hendl (2016) definuje tematickou analýzu jako „proces identifikace datových vzorců, datových konfigurací a témat v kvalitativních datech" a hodnotí ji jako pružnou a široce použitelnou metodu, která není úzce vázána na konkrétní teorii nebo pouze na jeden typ epistemologie. Tuto pružnost zařazuje jak mezi její výhody, tak současně i mezi nevýhody, a to především v souvislosti s rizikem obtížnější koncentrace na zásadní témata. Překážky a rizika spojená $s$ využitím tematické analýzy uvádějí v podobném smyslu prakticky všichni autoři; Boyatzis (1998) například spatřuje jisté nebezpečí ve výzkumníkově projekci, ve vzorkování a v naladění a stylu zpracování. Přesto je tematická analýza mimo jiné i součástí osvědčených komplexních výzkumných postupů, jako například metody zakotvené teorie. 
Vlastní struktura a postup aplikace tematické analýzy nejsou zcela přesně a jednoznačně kodifikovány. Boyatzis (1998) například uvádí čtyři stupně tematické analýzy (1. vycítění nebo tušení témat, 2. identifikování kódovatelných prvků $\mathrm{v}$ datovém souboru, 3. vytváření kódů - tedy vlastní kódování a 4. interpretaci nalezených témat v kontextu teoretického a koncepčního rámce). Hendl (2016) naproti tomu popisuje dokonce šest fází, a to seznámení s daty, generování počátečních kódů, vyhledávání témat, propracování témat a jejich revizi, vymezení a pojmenování témat a př́ipravu finální zprávy. Fakticky je ale na první pohled jádro metody vždy stejné, autoři se liší pouze $\mathrm{v}$ míre podrobnosti strukturace jednotlivých kroků (u Hendla jsou proto navíc samostatně uvedené operace tematizování a finální deskripce interpretovaných výsledků).

Východiskem je vždy tzv. datový korpus (Hendl, 2016), v našem případě podstatná část dokumentu (nástroje) Ukazatel inkluze, která obsahuje parametry inkluzivního vzdělávání a hodnoticí měřítka pro evaluaci úrovně procesu inkluzivní edukace. Má-li být výsledkem tematické analýzy nalezení témat, znamená to podle Hendla (2016), že musíme nalézt „něco důležitého v datech" (určité významy nebo konfigurace); co konkrétně to bude, však závisí zcela na výzkumníkovi. Dokument proto musíme podrobit nejprve kódování a následně kategorizaci, při které teprve lze vyčíst zásadní témata. ${ }^{5}$

Pro analýzu Ukazatele inkluze jsme použili u nás nejdostupnější verzi jeho překladu do češtiny publikovanou organizací Rytmus v roce 2007 (Booth \& Ainscow, 2007). Protože materiál byl vydán před relativně delší dobou a není také v překladech plně adaptován na místní podmínky, upravujeme některé drobné (zejména terminologické) odlišnosti tak, aby odpovídaly stavu a terminologii platné legislativy a situace v naší zemi - aby tedy analýza odrážela naše aktuální reálie a byla čtenářům dobře srozumitelná.

Analýzu jsme provedli induktivní formou. Vycházíme tedy z analyzovaného dokumentu (Ukazatele inkluze), ve kterém jsme vyhledali a identifikovali (kódovali) informace týkající se pojetí odlišnosti (rozmanitosti) a přístupu $\mathrm{k}$ tomuto fenoménu v inkluzivní škole. Analyzovaná část materiálu je koncipována jako autoevaluační dotazník sestavený z výroků, na které má uživatel

Obsah pojmů „kategorie“ a „téma“ bývá někdy nesprávně zaměňován; zatímco témata musí být vždy výsledkem tematické analýzy, kategorizace kódů může dosahovat různých úrovní od prostého zpřehlednění nalezených kódů až po vytváření tzv. „subtémat“, což ovšem není vždy nutné. 
(respondent) reagovat kladnou nebo zápornou odpovědí a současně určením podrobnější úrovně konkrétního parametru reflektované v pozitivním nebo negativním směru. $V$ obsahu dotazů se intenzivně mísí odkazy a důrazy na to společné (shodné) a na to individuálně odlišné (rozdílné). Identifikace parametrů zaměřených na odlišnosti vyžaduje proto jistou citlivost, nebot' i prvky označující to společné získávají často svůj smysl a odraz ve vztahu školy ke zřejmým odlišnostem (respektovaná heterogenita např. implikuje potřebu specifické podpory pro některé žáky atd.).

Kódy (jako významově související výroky) vztahující se $\mathrm{k}$ postojům a př́istupu k odlišnostem byly identifikovány ve všech třech sledovaných oblastech Ukazatele prrímo $\mathrm{v}$ jednotlivých položkách měřítek, a to i na základě detailních (nikoliv však vyčerpávajících) přehledů otázek doporučených pro evaluaci každé jednotlivé položky. Pokud tedy není kód zjevný už v samotné formulaci položky, mohl být zřetelně identifikován právě ze seznamu evaluačních otázek. Podrobná nabídka evaluačních dotazů nám tak poskytla upřesnění (podklad) pro správné porozumění významu formulace každé položky. Identifikované kódy pak byly podle významových souvislostí rozřazeny do čtyř skupin zrcadlících konkrétní témata (vytváření hlubší struktury podtémat $\mathrm{v}$ našem případě nebylo nutné vzhledem $\mathrm{k}$ omezenému množství kódů a poměrně zřetelné přímé identifikaci jednotlivých témat).

\section{Identifikovaná témata}

Pomocí otevřeného a selektivního kódování byla ve všech třech oblastech měřítek Ukazatele inkluze nalezena a definována následující témata vztahující se bezprostředně k prvku odlišnosti (jinakosti) v prostředí inkluzivní školy:

\section{Akceptace}

Téma akceptace (ve smyslu vzájemného přijetí, tolerance atd.) jsme rozpoznali na základě tří kódů označených jako:

- Přijetí každého žáka (měřítka A.1.1 a B.2.7) - Ukazatel inkluze zde například výslovně apeluje na přijímání romských žáků nebo žáků s postižením přichází také s požadavkem na komunikační přizpůsobení vůči žákům se smyslovým postižením, vstřícnost vůči žákům z jiných etnických menšin nebo citlivé a opatrné uplatňování restriktivních postupů vůči žákům s kázeňskými problémy. 
- Pozitivní postoj $k$ odlišnostem (měřítka C.1.3 a C.2.1) - nejde pouze o formální respekt k odlišnostem a informovanost žáků o kulturních, etnických, náboženských a jiných rozdílnostech, ale také o př́ležitost přímého osobního kontaktu a spolupráce s takto odlišnými spolužáky nebo i pracovníky školy; inkluzivní škola si cení jejich přítomnosti, příležitostí pro vytváření vstřícných postojů má být třeba projektová výuka zaměřená na poznání odlišných kultur a skupin.

- Vzájemnost a sdílení (měřítka A.1.2 a A.2.2) - pozornost je věnována povědomí žáků o velmi odlišných limitech některých spolužáků, včetně například jejich omezené schopnosti dodržovat určitá školní pravidla a normy, aniž by to bylo vnímáno jako nespravedlivé. Je vyžadován aktivní boj proti názoru, že inkluze má své meze a některé žáky ve škole zkrátka akceptovat nelze; zdůrazňováno je i uvědomění faktu, že exkluze některých žáků se odehrává v učitelských kabinetech (kde pedagogové přemýšlejí a mluví o některých žácích) nebo při mimoškolních aktivitách.

\section{Dostupnost}

Druhé téma se týká bezbariérové přístupnosti prostor školy, stejně jako psychosociální bezbariérovosti nebo také dostupných př́ležitostí $\mathrm{k}$ úspěchu každého žáka. Rozpoznanými kódy jsou zde:

- Prostorová a komunitní bezbariérovost (měřítka A.1.7, B.1.3, B.1.4 a C.2.4) - samozřejmostí má být plná architektonická bezbariérovost školy, zapojení místních komunit do fungování školy bez ohledu na jejich sociokulturní, náboženské nebo etnické zázemí a opět přístupnost i pro děti z menšinových etnik nebo těch rodin, které se často stěhují a pobývají souvisle ve škole třeba kratší dobu. Akcentována je motivace žáků se speciálními vzdělávacími potřebami pro výběr místní školy nebo i jejich přechod do této školy ze školy speciální. Do života školy mají být zapojováni i dospělí lidé s postižením (jako zaměstnanci nebo sympatizující příslušníci místní komunity) a také celá lokální infrastruktura, která může poskytnout využitelné zdroje při edukaci žáků (knihovny, spolky, úřady, volnočasová zařízení apod.).

- Bezbariérovost edukačního procesu (měřítka A.2.5, B.2.2, B.2.3, B.2.4 a C.1.1) znamená nesledovat překážky primárně na straně žáků, ale v parametrech a procesech fungování samotné školy; očekává se dobrá příprava a rozvoj kompetencí učitelů pro práci s heterogenní skupinou žáků 
a odstraňování labelingu některých žáků. Adekvátně by měla být využívána pozice koordinátora inkluze i ostatních běžných poradenských služeb přímo ve škole, a to zejména v edukaci žáků s diagnostikovanou potřebou podpory. Důležité je také odstraňovat kulturní, komunikační a rovněž genderové překážky ve vyučování.

- Snižování sociálních prahů (měřítka B.2.8 a C.1.11) vyžaduje větší zaměření na podporu pravidelné školní docházky než na následnou restrikci $\mathrm{z}$ důvodu neomluvených absencí (s přihlédnutím $\mathrm{k}$ individuální situaci konkrétních žáků). Nacházíme zde také požadavek stejné míry skupinové heterogenity ve volnočasových aktivitách zajištovaných školou, jaká je běžná i při výuce ve tř́dách této školy.

\section{Podpora}

Téma podpory je saturováno kódy:

- Př́má edukační podpora (měřítka B.2.5, C.1.2, C.1.9 a C.2.3) - ta zahrnuje podporu komunikace pro žáky s odlišným mateřským jazykem nebo kulturním zázemím (včetně např. žáků s vrozeným těžkým postižením sluchu), dále návrh využívání metajazyka pro společné pochopení souvislostí ve výuce a předpoklad emoční podpory a empatického pochopení pro žáky s fyzickým nebo jiným hendikepem. Standardem by mělo být využívání moderních technologií, elektronické komunikace a digitalizovaných materiálů či audiovizuálních pomůcek pro žáky se smyslovým postižením.

- Adaptační podpora (měřítka B.1.5, B.2.1 a C.2.5) předpokládá nejenom systémovou, institucionálně zajištěnou podporu, ale také vrstevnickou pomoc ze strany spolužáků (včetně kamarádů, kteří pomohou žákovi $\mathrm{s}$ orientací $\mathrm{v}$ novém prostředí). Veškerá vzdělávací podpora pro žáky má být školou koordinována - jak ta poskytovaná přímo ve škole, tak i ta zprostředkovávaná mimoškolními institucemi (např. školskými poradenskými zařízeními). Všichni, kdo se žáky pracují, by měli také vědět o veškerých zdrojích využitelných pro podporu žáků, které jsou v rámci školy dostupné. 


\section{Antidiskriminace}

Kódy související úzce s tématem antidiskriminace jsme nazvali:

- Rovnocenný přístup (měřítka A.2.1, A.2.3, B.1.6 a C.1.6) - inkluzivní škola nepodporuje porovnávání žáků mezi sebou, ale rozvíjí u nich schopnost ocenit úspěch svůj i druhých, a naopak vyhnout se negativní a nekonstruktivní kritice a negativnímu hodnocení každého okamžitého neúspěchu. Žádoucí je oceňování i drobných pokroků s ohledem na individuální možnosti a limity jednotlivých žáků; výsledky v učení nesmějí být v této škole kritériem pro hodnocení žáků jako takových. Inkluzivní škola je otevřená pro žáky i učitele s postižením stejně jako pro ty bez postižení - proto se vyhýbá rozřazování žáků podle výkonu nebo jiných diskriminačních znaků (např. zdravotního postižení); neinklinuje tedy k vytváření homogenních skupin, ale pokouší se zajistit rovnováhu (včetně té genderové) a v heterogenních skupinách nastavovat podmínky přibližně stejně výhodné pro všechny. Hodnocení je především formativní, kooperativní a citlivé.

- Protidiskriminační opatření (měřítka A.2.6, B.1.1 a B.2.9) mají zajistit zamezení institucionální diskriminace a snižovat tlak na exkluzi žáků ze sociokulturně a etnicky odlišného prostředí. Odmítána je jakákoliv stereotypizace (genderová, etnická apod.). Nediskriminující přístup by měl být zjevný i v personální politice školy, a tedy v zastoupení různých sociálních skupin mezi zaměstnanci školy (opět včetně genderových i věkových parametrů). Nejenom formálně, ale prakticky musí být ve škole efektivně zamezováno jakékoliv šikaně, a to ve všech jejích formách (riziko šikany musí být prokazatelně snižováno na minimum).

Tabulka 1

Přehled identifikovaných témat na základě nalezených kódů

\begin{tabular}{llll}
\hline AKCEPTACE & DosTuPNOST & PODPORA & ANTIDISKRIMINACE \\
\hline $\begin{array}{l}\text { A.1.1 Každý se cítí } \\
\text { vítán }\end{array}$ & $\begin{array}{l}\text { A.1.7 Do školy se } \\
\text { zapojují všechny místní } \\
\text { komunity }\end{array}$ & $\begin{array}{l}\text { B.1.5 Všem novým } \\
\text { studentům se } \\
\text { pomáhá, aby si } \\
\text { ve škole zvykli }\end{array}$ & $\begin{array}{l}\text { A.2.1 Od všech } \\
\text { studentů se toho } \\
\text { hodně očekává }\end{array}$ \\
$\begin{array}{l}\text { A.1.2 Studenti si } \\
\text { navzájem pomáhají }\end{array}$ & $\begin{array}{l}\text { A.2.5 Zaměstnanci } \\
\text { školy se snaží } \\
\text { odstraňovat překážky } \\
\text { v učení a zapojení } \\
\text { ve všech aspektech } \\
\text { školy }\end{array}$ & $\begin{array}{l}\text { B.2.1 Všechny } \\
\text { formy podpory jsou } \\
\text { koordinovány }\end{array}$ & $\begin{array}{l}\text { A.2.3 Studenti jsou } \\
\text { ceněni stejně }\end{array}$ \\
& & & \\
\hline
\end{tabular}




\begin{tabular}{|c|c|c|c|}
\hline AKCEРTACE & DOSTUPNOST & PODPORA & ANTIDISKRIMINACE \\
\hline $\begin{array}{l}\text { A.2.2 Zaměstnanci } \\
\text { školy, členové jejího } \\
\text { správního orgánu, } \\
\text { studenti a rodiče/ } \\
\text { pečovatelé sdílejí } \\
\text { myšlenku inkluze }\end{array}$ & $\begin{array}{l}\text { B.1.3 Škola dbá na to, } \\
\text { aby přijímala všechny } \\
\text { studenty ze své } \\
\text { spádové oblasti }\end{array}$ & $\begin{array}{l}\text { B.2.5 Podpora } \\
\text { pro ty, kteří se } \\
\text { učí angličtinu } \\
\text { jako cizí jazyk, } \\
\text { je koordinována } \\
\text { s podporou učení }\end{array}$ & $\begin{array}{l}\text { A.2.6 Škola se snaží } \\
\text { minimalizovat } \\
\text { všechny formy } \\
\text { diskriminace }\end{array}$ \\
\hline $\begin{array}{l}\text { B.2.7 Tlak } \\
\text { na vyloučení } \\
\text { z kázeňských } \\
\text { důvodů je omezen }\end{array}$ & $\begin{array}{l}\text { B.1.4 Škola dbá na to, } \\
\text { aby byly její prostory } \\
\text { fyzicky dostupné všem } \\
\text { osobám }\end{array}$ & $\begin{array}{l}\text { C.1.2 V hodinách se } \\
\text { podporuje zapojení } \\
\text { všech studentů }\end{array}$ & $\begin{array}{l}\text { B.1.1 Jmenování } \\
\text { zaměstnanců školy } \\
\text { do funkcí a jejich } \\
\text { kariérní postup jsou } \\
\text { spravedlivé }\end{array}$ \\
\hline $\begin{array}{l}\text { C.1.3 V hodinách se } \\
\text { rozvíjí porozumění } \\
\text { odlišnostem }\end{array}$ & $\begin{array}{l}\text { B. } 2.2 \text { Činnosti v oblasti } \\
\text { rozvoje zaměstnanců } \\
\text { napomáhají } \\
\text { zaměstnancům } \\
\text { školy reagovat } \\
\text { na různorodost } \\
\text { studentů }\end{array}$ & $\begin{array}{l}\text { C.1.9 Asistenti } \\
\text { učitele podporují } \\
\text { učení a zapojení } \\
\text { všech studentů }\end{array}$ & $\begin{array}{l}\text { B.1.6 Škola sestavuje } \\
\text { učební skupiny tak, } \\
\text { aby byli doceněni } \\
\text { všichni studenti }\end{array}$ \\
\hline \multirow[t]{6}{*}{$\begin{array}{l}\text { C.2.1 Rozdíly } \\
\text { mezi studenty se } \\
\text { využívají jako zdroj } \\
\text { pro výuku a učení }\end{array}$} & $\begin{array}{l}\text { B.2.3 Koncepce } \\
\text { „speciálních } \\
\text { vzdělávacích potřeb“ } \\
\text { jsou inkluzivní }\end{array}$ & $\begin{array}{l}\text { C.2.3 Zaměstnanci } \\
\text { školy vytvářejí } \\
\text { zdroje na podporu } \\
\text { učení a zapojení }\end{array}$ & $\begin{array}{l}\text { B.2.9 Šikana } \\
\text { je omezena } \\
\text { na minimum }\end{array}$ \\
\hline & $\begin{array}{l}\text { B.2.4 Za účelem } \\
\text { omezení překážek } \\
\text { v učení a za účelem } \\
\text { zapojení všech } \\
\text { studentů se používá } \\
\text { prováděcí předpis pro } \\
\text { speciální vzdělávací } \\
\text { potřeby }\end{array}$ & $\begin{array}{l}\text { C. } 2.5 \text { Školní zdroje } \\
\text { jsou spravedlivě } \\
\text { rozdělovány, aby } \\
\text { podporovaly inkluzi }\end{array}$ & $\begin{array}{l}\text { C.1.6 Hodnocení } \\
\text { přispívá k dobrým } \\
\text { výsledkům všech } \\
\text { studentů }\end{array}$ \\
\hline & $\begin{array}{l}\text { B.2.8 Omezují se } \\
\text { překážky v docházce }\end{array}$ & & \\
\hline & $\begin{array}{l}\text { C.1.1 Výuka je } \\
\text { plánována s ohledem } \\
\text { na to, aby se učili } \\
\text { všichni studenti }\end{array}$ & & \\
\hline & $\begin{array}{l}\text { C.1.11 Všichni } \\
\text { studenti se účastní } \\
\text { mimoškolních aktivit }\end{array}$ & & \\
\hline & $\begin{array}{l}\text { C. } 2.4 \text { Zdroje } \\
\text { v komunitě jsou známy } \\
\text { a využívají se }\end{array}$ & & \\
\hline
\end{tabular}




\section{Diskuze a stručná reflexe přístupu k rozmanitosti v inkluzivní škole}

Na první pohled je zřejmé, že přístup k rozdílnosti (odlišnosti, jinakosti...) je v koncepci inkluzivní školy prezentován a formulován téměř výhradně pozitivním způsobem (negativně formulovaných výroků je v souvislosti s tímto zásadním prvkem v Ukazateli inkluze minimum). Všechna čtyři identifikovaná témata obsahují jak praktické (nebo přímo materiální) konotace, tak i zacílení na složku názorů, postojů a dalších psychosociálních projevů. Řada požadavků je v současnosti již zarámovaná i legislativními opatřeními. Velmi snadno si lze čtyři formulovaná témata představit jako vrstvy, které však nelze jednoznačně uspořádat do hierarchické struktury (spíše se prolínají a doplňují, než aby vykazovaly zřetelný poměr nadřazenosti a podřazenosti). Důležitá je jejich vzájemná provázanost; jestliže některá škola např́íklad aplikuje podporu pro žáky se speciálními vzdělávacími potřebami (v podobě doporučených podpůrných opatření), ale nezabývá se tématem skutečného přijetí těchto žáků ze strany spolužáků, učitelů, ostatních zaměstnanců školy, příp. i rodičů a dalších členů místní komunity, snaží se sice o „společné vzdělávání", ale nelze ji označit za skutečně inkluzivní. Ani když zajistí bezchybnou architektonickou bezbariérovost, nevyloučí totiž existenci ještě závažnějších psychologických a sociálních bariér a potenciálně v ní nepochybně zůstává riziko různých forem diskriminace. Podobně bychom mohli jmenovat další možné prŕíklady nekomplexního přístupu k základním inkluzivním tématům.

Témata akceptace, dostupnosti, podpory a antidiskriminace mohou ukazovat také na jistý cyklický proces: jestliže se škola rozhodne skutečně akceptovat různé žáky (i pracovníky), nevyhnutelně musí něco udělat pro to, aby se těmto žákům (nebo i zaměstnancům) stala dostatečně dostupnou (po všech stránkách). Aby pak tito žáci (a zaměstnanci) mohli ve škole úspěšně působit - tedy vzdělávat se nebo se podílet na fungování školy, je nezbytné jim poskytovat a zprostředkovávat přiměřenou podporu a omezovat na minimum všechny možné prvky diskriminace, které by mohly vést $\mathrm{k}$ neúspěchu těchto jedinců, eventuálně i k jejich opuštění školy. Tím by totiž byla popřena vstrrícnost a připravenost školy k přijetí různých žáků a pracovníků (opět se tedy ocitáme u prvního identifikovaného tématu). Ukazatel inkluze má školám v praxi pomoci nejenom úspěšně tento inkluzivní kruh uzavřít, ale až do maximální možné míry naplňování popsaných parametrů zvyšovat (zkvalitňovat). Ve skutečnosti se tím tedy inkluzivní kruh mění v inkluzivní spirálu, která má svoji hranici tam, kam sahají maximální možnosti konkrétní školy. 
V nalezených kódech (resp. v podrobných evaluačních dotazech u jednotlivých měřítek) se objevuje místy snad až příliš ostré zacílení na etnické menšiny, například v souvislosti s dodržováním pravidelné docházky do školy nebo s častými problémy v chování - to může působit zbytečně nálepkujícím dojmem (ne-li dokonce jako ukázková stereotypizace). Protože autoři Ukazatele vybízejí ke kreativnímu přístupu k celému materiálu (při zachování základního významu a hodnotového rámce), můžeme jen doporučit při využití tohoto nástroje jeho úpravu a „pročištění" tak, aby žádné pasáže nevzbuzovaly pochybnosti z hlediska současného inkluzivního diskurzu v našich podmínkách. Není tedy nutné (a možná ani vhodné) přemýšlet konkrétně například o žácích romského etnika, ale pracovat s problematikou žáků ohrožených školní neúspěšností, žáků pocházejících ze sociálně vyloučeného nebo sociokulturně znevýhodněného prostředí apod. Toto širší vymezení navíc poskytuje prŕležitost pochytit specifika i takových žákủ, kteří by při úzkém (např. etnickém) vymezení zůstali nepovšimnuti.

Velmi progresivně naopak Ukazatel inkluze myslí v různých oblastech i na roli a zapojení (přínos) učitelů, rodičů nebo dalších členů místní komunity, kteří patří sami do kategorie osob se zdravotním postižením nebo sociálním znevýhodněním - to by se mohlo pro naše školy stát velmi dobrou inspirací. Zatímco očekávání genderové vyváženosti pedagogických týmů v základních a středních školách je u nás $\mathrm{v}$ současnosti asi spíše jen virtuálním přáním (ze známých důvodů výrazná převaha žen mezi pedagogickými pracovníky dlouhodobě přetrvává), o dalších typech personální heterogenity české školy momentálně pravděpodobně ani neuvažují.

\section{Závěr}

Na základě analýzy Ukazatele inkluze jsme jako témata odrážející přístup inkluzivní školy k rozmanitosti (resp. k odlišnostem) identifikovali akceptaci, dostupnost, podporu a antidiskriminaci. Všechny tyto pojmy se frekventovaně vyskytují i v diskuzích nad problematikou společenského začleňování různě znevýhodněných osob (nejenom v odborném diskurzu, ale i v médiích). Až nápadně tato identifikovaná témata znovu zdůrazňujíjiž několikrát uvedenou myšlenku, kterou můžeme připomenout terminologií samotného Ukazatele inkluze - totiž že inkluze ve vzdělávání je pouze jedním z aspektů inkluze ve společnosti. To je zatím stále spíše opomíjený fakt: inkluzivní vzdělávání není samostatným a izolovaným konceptem, ale neoddělitelně souvisí se sociální inkluzí osob s postižením a znevýhodněním a dalších minorit, které 
jsou v běžné společnosti ohroženy sociálním vyloučením. Proto ani samotný Ukazatel inkluze nepracuje aktivně pouze se striktně ohraničeným prostředím školy, ale i s místní komunitou, municipalitou nebo rodinami žáků. Na to u nás momentálně prosazovaný koncept „společného vzdělávání“ (pokoušející se většinou pouze jaksi technologicky naplnit legislativní požadavky) prakticky nepomýšlí.

Podle Boardmana, Killaspy a Mezey (2010) mají koncepty sociální inkluze a exkluze výrazné morální a politické konotace, a to se týká i přístupu k rozmanitosti v širších souvislostech a v širším sociálním prostředí. Jestliže spolu s Jankovským (2003) budeme chápat politiku jako morálku společnosti, je zřejmé, že na národní i evropské politické scéně momentálně sledujeme nesnadnou diskuzi právě $\mathrm{k}$ tématu vztahu $\mathrm{k}$ „těm odlišným“ a že to (byt' zatím zdánlivě nepřímo) souvisí i s dalším přístupem k sociální inkluzi a také k inkluzivnímu vzdělávání. K tomu však zároveň musí nalézt vlastní postoj i každý člověk individuálně - a postoje se pak promítají v rovině etiky lidského jednání, připustíme-li s Jankovským (2003) pochopení etiky jako morálky jedince. A protože mezi morálkou společnosti a morálkou jedince nevede vždy přesná hranice, nebot' se vzájemně ovlivňují a vytvářejí jakési spojité nádoby, bude si nutné stále aktivněji vymezovat a hlídat kvalitu osobního postoje a prŕístupu k odlišnosti druhých lidí. To platí i pro pedagogy v běžných školách, které jsou nuceny postupně se transformovat ve školy více heterogenní; otázkou však zůstává, do jaké míry to nakonec bude skutečně transformace ve smyslu naplňování parametrů inkluzivní edukace. Aby přechod k inkluzivnímu vzdělávání byl opravdu úspěšný, nestačí k tomu legislativní úpravy a formální tlaky. Bude muset dojít k závažným a hlubokým proměnám kultury, politiky a praxe škol tak, aby odpovídaly rozmanitosti všech žáků v místní komunitě (Ainscow 2015, s. 111). V opačném případě se může stát, že nakonec přece jenom zvítězí hlasy, které dnes podle Ekinsové (2017) označují inkluzi jako naivní koncept prosazující se pouze díky snaze o extrémní politickou korektnost. Inkluzivní změny se nemohou odehrávat pouze za dveřmi škol - resp. pokud se o ně budeme pokoušet pouze tam, nemohou mít potřebnou kvalitu ani záruku trvalosti. Jak uzavírají také Imray a Colley (2017), zůstane-li inkluze omezená úzce na oblast školního vzdělávání, je už nyní v podstatě mrtvá; pokud se ji ale podaří prosazovat jako pevnou součást široké sociální inkluze, může to být neobyčejně životaschopný koncept. 


\section{Literatura}

Ainscow, M. (2015). Struggles for equity in education: The selected works of Mel Ainscow. London: Routledge.

Ainscow, M., Booth, T., \& Dyson, A. (2006). Improving schools, developing inclusion. London: Routledge.

Armstrong, A. Ch., Armstrong, D., \& Spandagou, I. (2010). Inclusive education: International policy and practice. Los Angeles: SAGE.

Artiles, A. J., Kozleski, E. B., \& Waitoller, F. R. (2011). Inclusive education: Examining equity on five continents. Cambridge: Harvard Education Press.

Bartoňová, M., Vítková, M., Bočková, B., Bytešníková, I., Hloušková, L., Horáková, R., ... Opatřilová, D. (2016). Inkluze ve škole a ve společnosti jako interdisciplinární téma. Brno: Masarykova univerzita.

Boardman, J., Killaspy, H., \& Mezey, G. (Eds.). (2010). Social inclusion and mental health. London: RCPsych Publications.

Booth, T., \& Ainscow, M. (2002). Index for inclusion: Developing learning and participation in schools. Bristol: CSIE.

Booth, T., \& Ainscow, M. (2007). Ukazatel inkluze: rozvoj učení a zapojení ve školách. Praha: Rytmus. Dostupné z http://www.csie.org.uk/resources/translations/IndexCzech.pdf

Boyatzis, R. E. (1998). Transforming qualitative information: Thematic analysis and code development. Thousand Oaks: Sage Publications.

Brown, Z. (2016). Inclusive education: perspectives on pedagogy, policy and practice. New York: Routledge.

Dinh Thi, N., \& Le Thu, H. (2010). How-to guide: Preparing teachers for inclusive education. Baltimore: Catholic Relief Services.

Ekins, A. (2017). Reconsidering inclusion: Sustaining and building inclusion practices in schools. New York: Routledge.

Farrell, P., \& Ainscow, M. (Ed.). (2002). Making special education inclusive from research to practice. London: David Fulton.

Forlin, C. (2010). Teacher education for inclusion: Changing paradigms and innovative approaches. London: Routledge.

Hájková, V., \& Strnadová, I. (2010). Inkluzivní vzdělávání. Praha: Grada.

Hendl, J. (2016). Kvalitativní výzkum: základní teorie, metody a aplikace. Praha: Portál.

Hornby, G. (2014). Inclusive special education. New York: Springer-Verlag.

Imray, P., \& Colley, A. (2017). Inclusion is dead. Long live inclusion. New York: Routledge.

Jandourek, J. (2008). Průvodce sociologií. Praha: Grada.

Jankovský, J. (2003). Etika pro pomáhající profese. Praha: Triton.

Lechta, V. (Ed.). (2016). Inkluzivní pedagogika. Praha: Portál.

Lombardi, T. P. (1999). Inclusion: Policy and practice. Bloomington: Phi Delta Kappa.

Miovský, M. (2006). Kvalitativní př́stup a metody v psychologickém výzkumu. Praha: Grada.

Tannenbergerová, M. (2016). Průvodce školní inkluzí aneb Jak vypadá kvalitní základní škola současnosti? Praha: Wolters Kluwer.

Westwood, P. S. (2013). Inclusive and adaptive teaching: Meeting the challenge of diversity in the classroom. New York: Routledge. 


\title{
Autor
}

PhDr. Josef Slowík, Ph.D., Katedra pedagogiky, Fakulta pedagogická, Západočeská univerzita v Plzni, Chodské nám. 1, 30614 Plzeň, email: slowik@kpg.zcu.cz

\section{What is diverse and what is common in an inclusive school in terms of the Index for inclusion}

\begin{abstract}
The study analyzes basic characteristics of inclusive education related to diversity (otherness) based on the indicators and parameters used in Index for inclusion. In the first part, there is presented a paradigm of inclusive education and how this concept refers to the topic of "common" and "different". A typical inclusive openness to welcoming acceptance of diversity, difference, and otherness is showed in a connection to the stapling elements of common values which are fundamental in an inclusive educational process. The next part is devoted to the thematic analysis od the Inclusion for inclusion (Booth \& Ainscow, 2007), a basic material frequently used as a standard of school inclusive education (and of their evaluation). Analysing all parameters of inclusive areas and their evaluation benchmarks, we have identified four key themes reflecting the approach of inclusive school to differences; those are Acceptance, Accessibility, Support and Antidiscrimination.
\end{abstract}

Keywords: inclusion, inclusive education, Index for inclusion, diversity 